Successful Salon MANAGEMENT 
Also from The Macmillan Education

Daniel Galvin The World of Hair Colour: the art and techniques of Modern Hair Colouring

Leo Palladino The Principles and Practice of Hairdressing 


\section{SucCessful Salon MANAGEMENT}

Psychology in Hairdressing

\section{ROGER CUFFE-THOMPSON}

Head of Department of Hair and Beauty Studies, Cannock Cbase Technical College, Cannock

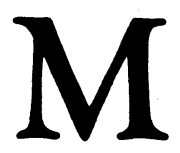


๑Roger Cliffe-Thompson 1982

Softcover reprint of the hardcover 1st edition 1982

All rights reserved. No part of this publication may be reproduced or transmitted, in any form or by any means, without permission.

First published 1982 by

THE MACMILLAN PRESS LTD

London and Basingstoke

Companies and representatives

throughout the world

Typeset in 11/12pt IBM Journal

by Thames Typesetting,

Abingdon

ISBN 978-1-349-06194-5

ISBN 978-1-349-06192-1 (eBook)

DOI 10.1007/978-1-349-06192-1 


\section{CONIENIS}

Preface vii

1 An Introduction to Some Psychological Concepts 1

Memory: how it works and what are its limitations; how best to give instructions to staff 1

Creativity: how to be more creative 9

Gain and loss of esteem and its effect on staff 14

Audience effects: what having an audience does to the hairdresser's performance $\quad 22$

Bystander apathy: what to do when things go wrong in the salon $\quad 25$

Conclusion $\quad 28$

2 How Creating a Good Impression Can Improve Your Business

Why is it good to look attractive? Is it important to have attractive staff?

Who do you blame when things go wrong? 37

When you are interviewing someone can first impressions lead you to make a wrong decision?

Does your appearance matter when you are giving advice?

What are the effects of the way you look at people and of the clothing you wear?

Conclusion

3 Impression Management in the Salon $\quad 47$

Introduction $\quad 47$

What is 'the looking-glass self'? $\quad 48$

How to create a good impression $\quad 50$ 
vi

The self-image of the client 52

Eye contact $\quad 56$

Smiling 61

Tone of voice $\quad 62$

Touch 63

Proximity $\quad 65$

Conclusion $\quad 68$

4 How to Improve Your Interviewing Skills 69

Some examples of interviewing situations 69

What is an interview? $\quad 71$

The problems of interviewing $\quad 72$

When is an interview useful? $\quad 73$

Creating the right conditions for good interviewing $\quad 73$

Preparing for the interview 76

The physical setting of the interview 77

Non-verbal communication in the interview $\quad 78$

$\begin{array}{ll}\text { The interview itself } & 79\end{array}$

The skills of interviewing $\quad 84$

Recording the interview $\quad 89$

How to end the interview $\quad 90$

What to do after the interview 91

Conclusion $\quad 92$

Interviewing skills checklist $\quad 94$

$\begin{array}{ll}\text { Conclusion } & 95\end{array}$

$\begin{array}{ll}\text { Further Reading } & 97\end{array}$ 


\section{Preface}

You've got to be a bit of a psychologist in this game!

There is a strong need within the hairdressing profession for a much greater understanding of human behaviour. Many but not all hairdressers now realise that a high financial profit and a contented clientele and staff are considerably more the results of an appropriate understanding of human behaviour than of a narrow-minded concentration on the mere mechanical aspects of hairdressing. The profession is in need of a book which not only deals with the understanding of why people behave in the way they do but also provides us with ways of controlling what we do so that we can become more efficient.

Psychology is the conscious study of human behaviour. It has formed many sub-disciplines, for example, cognitive psychology studies the workings of the human brain whereas social psychology is concerned with examining the effects of the social and cultural environment on individual behaviour and experience. Now I stress the word 'conscious' because it is the difference in meaning between conscious and unconscious that divides psychology from hairdressing. Psychologists consciously study human behaviour whereas hairdressers 'unconsciously' or 'subconsciously' study it and herein lies the reason for this book.

In hairdressing there are certain ways of performing a skill (for example, perming or tinting) which are common to most hairdressers. In addition to these commonly accepted ways there are lots of other ways of, say, sectioning and winding perms, or applying tints, that would achieve the desired result in the long run. However, they would not be as efficient timewise or in the consumption of materials. If you left an apprentice on her own for a few weeks to work out how to perm a head of hair, she might well succeed and might even 
discover the 'accepted' method. But it would be learning by trial and error, and the one commodity that this method of learning relies heavily on is time: something we can ill afford to waste in the salon! So naturally instruction in the skill of hairdressing has become an accepted part of the trade. But what about social skills? You may have also become naturally skilled and adept at dealing with people (otherwise you would not be a hairdresser), but are there more efficient ways of dealing with others? Can the way you act in a situation affect the human relations side of your business?

This book attempts to present to you some findings of psychologists which have direct application to your business and it is hoped that it will help you step back and view your own behaviour objectively and then decide on what specific strategies to adopt in order to make you a more efficient and successful hairdresser. Some of the information may appear to be simply common sense, but the study of human behaviour is not the prerogative of psychologists alone, and perhaps it will confirm what you have always felt about people and situations. But to know that others have studied experimentally the same phenomena and have come to the same conclusions as yourself can be very comforting and reassuring. For me one of the main sources of frustration in hairdressing is that although we are continually surrounded by people, we tend to be alone when we have to deal with them.

But remember, we are not trying to turn you into psychiatrists (who mostly study abnormal behaviour) or instant psychologists. Nor is this book a series of recipes for dealing with all of life's situations or the exploiting of others. It is meant simply as a way of presenting some facts and findings which relate to your own behaviour and that of others, and if applied, will make the working of your salon more harmonious and profitable.

As a former salon owner (and now a lecturer) I have for several years been convinced that a greater understanding of human psychology can be most beneficial to the hairdresser. Through my work with the Open University I met some academic psychologists who were able to translate effectively what they knew (and had researched) about human behaviour into a practical form which would be of direct relevance to the hairdressing profession. Together with these psychologists (in particular Ray Bull, B.Sc., M.Sc., A.B.Ps.S., and Denis Gahagan, B.A., A.B.Ps.S., who both wrote major parts of this book) I organised a considerable number of three-day residential courses 
on 'Psychology in Hairdressing' at the University of Nottingham. In all, several hundred people attended these courses. These people came from all parts of the profession-there were senior managers and managing directors of the largest companies, stylists from the most up-to-date salons, owners of just a few or one salon, and there were trainees. A frequent request made at the end of every course was for us to produce a book incorporating parts of our courses. This we have now done, and though our courses cover over twenty different topics we have endeavoured here, in the space available to us, to present information on some of the most important topics. Those wishing to ask me questions following their reading of this book, or to enquire about our courses, should feel free to contact me.

I hope that you will enjoy this book.

Roger Cliffe-Thompson 